\title{
Croatia: Time to re-evaluate employment policy
}

\begin{abstract}
The current situation on the Croatian labour market does not look very promising. The global financial and economic crisis has only emphasised the already existing problems. Croatia has the lowest employment rate in the EU which, together with a two-digit unemployment rate, clearly indicates internal structural explanations. The main culprit for the lack of the necessary dynamics in labour market flows is labour demand. Faced with an absence of domestic and foreign investment, rigid employment protection laws and high tax burdens, it is almost impossible for firms to create new jobs and expand overall labour demand. Employment policies should help in this kind of situation, but an assessment of employment policies in Croatia reveals that there are more weaknesses than strengths among the internal factors. Relying only on accession to the $\mathrm{EU}$ in a situation of reasonably unfavourable economic conditions does not seem like the best strategy. In order to improve employment potential, Croatia should rely more on internal strengths and institutional conditions.
\end{abstract}

Keywords: economic crisis, employment rate, unemployment, youth unemployment, tax wedge, education and training system, active labour market measures, demographic change, aging labour force, migration trends

\section{Labour market situation}

Croatian labour market development trends in the period between 2006 and 2010 clearly show the impact of the global economic crisis, the effect of which was modest as regards labour demand in 2008 but which increased in intensity during the following years. Negative economic activity in 2009 (-6.0\% change in real GDP) and in 2010 (-1.2\%), accompanied by a drop of $-0.8 \%$ in the first quarter of 2011 (EIZ, 2011), have had an adverse effect on the labour market. These trends have resulted in reduced employment and in increased unemployment, which has spread across all age groups, affecting to a somewhat greater extent both older and younger groups.

The significant increase in unemployment rates was due to a loss of jobs and decreased new employment possibilities. According to Eurostat statistics, it seems that, at the beginning of the global crisis, the demand for labour in Croatia was not hit as hard as in other countries in the region, but only the later evidence (from 2010 to 2012) is able to demonstrate how long the problems have lasted in each country. In the first half of 2011, the total number of registered unemployed people in Croatia declined slightly, but it is still too early to conclude whether this is only a temporary improvement or a continuing declining trend. There are some warnings that the duration of the recovery of the labour market in Croatia will be longer than in some other countries (Eurostat). 


\section{Employment rates}

Employment growth in the period from 2006 to 2010 in Croatia shows a declining trend starting from 2008 (Table 1). The negative growth rate continued up to 2010, but the data seems to show a small amount of recovery at the beginning of 2011 (EIZ, 2011). However, employment rates in Croatia are continuously below the average employment rates in EU-15 countries. When compared to other countries in the region, Croatia has a similar employment rate to Hungary, but it is lower than all other new EU member states. The Croatian employment rate (for people aged 15-64) is one of the lowest in Europe: it was around $57 \%$ in 2009 and declined further to $54 \%$ in 2010 (Figure 1). A breakdown by gender shows that there is a male predominance to the employment rate in Croatia, in keeping with the pattern in the majority of countries in the EU.

Despite the impact of the financial and economic crisis, there are structural influences embedded in the low employment rate, such as the duration of education for the young cohort of the population of working-age (between 15 to 24 years), as well as the employment rate of older workers (aged 55-64). In 2010, the older-age male employment rate in Croatia was $49.2 \%$ (women: $27.3 \%$ ), ${ }^{1}$ in comparison with an average of $54.6 \%(38.6 \%)$ in the EU-27. Traditional reasons for lower female employment also influence the overall lower employment rate, but the most problematic evidence is that of male employment amongst those of prime age (25-54). Men in the prime-age group in Croatia have an extremely low employment rate of only $74.7 \%$ in comparison with the average in the EU-27, which was 83.9 in $2010 .^{2}$ This means that a large part of the male labour force in their prime working age are not (officially) working. Female employment rates in the prime-age group are lagging behind in comparison with other countries within the EU-27 as well as with respect to male employment rates in the equivalent group.

The generally low employment rate among the prime-age cohort in Croatia is the core problem facing employment policy, regardless of specific employment difficulties at the point of entrance to, or exit from, the labour market. Evidently, this is primarily a problem of labour demand, caused by insufficient new job creation and an absence of domestic and foreign investment.

Looking at how the crisis has hit employment rates on the basis of gender and age, there is no difference between Croatia and EU countries. Men have been hit more than women, and younger more than older cohorts.

1 CES (2011) Analytical Bulletin No. 2, pp. 18-19.

2 ibid. p. 16. 
Table 1 - Employment growth and employment rates in Croatia, 2006-2010

\begin{tabular}{|l|r|r|r|r|r|}
\hline & $\mathbf{2 0 0 6}$ & $\mathbf{2 0 0 7}$ & $\mathbf{2 0 0 8}$ & $\mathbf{2 0 0 9}$ & $\mathbf{2 0 1 0}$ \\
\hline Employment growth (\% change from previous & & & & & \\
period) & -0.6 & 3.5 & 1.1 & -1.8 & -4.0 \\
EU-15 average & 1.5 & 1.6 & 0.7 & -1.8 & -0.3 \\
\hline Employment rate, age 15-64 total & 55.6 & 57.1 & 57.8 & 56.6 & 54.0 \\
EU-15 average & 66.2 & 66.9 & 67.3 & 65.9 & 65.4 \\
Employment rate, age 15-64 (male) & 62.0 & 64.4 & 65.0 & 62.4 & 59.4 \\
Employment rate, age 15-64 (female) & 49.4 & 50.0 & 50.7 & 51.0 & 48.8 \\
\hline Employment rate of older workers (55-64) & 34.3 & 35.8 & 36.7 & 38.4 & 37.6 \\
EU-15 average & 45.3 & 46.5 & 47.4 & 47.9 & 48.4 \\
\hline Part-time workers (\% of total employment) & 9.4 & 8.6 & 8.8 & 9.0 & 9.7 \\
\hline Employed people with a second job - annual & & & & & \\
average (000) & 47.9 & 47.9 & 50.3 & 47.2 & 42.3 \\
\hline Employment rate (15-64), by NUTS 2 region & & & & & \\
North & $\mathrm{n} / \mathrm{a}$ & 62.4 & 63.1 & 62.1 & 60.4 \\
Middle & $\mathrm{n} / \mathrm{a}$ & 52.5 & 53.7 & 52.2 & 48.3 \\
Adriatic & $\mathrm{n} / \mathrm{a}$ & 55.1 & 55.0 & 53.9 & 51.7 \\
\hline
\end{tabular}

Source: Eurostat.

The low employment rates in Croatia are based mainly on full-time employment. Each of the long-standing EU member states uses part-time employment in different ways, but all are using it more than are new member states. This is the result of an institutionally-entrenched culture of work which does not easily recognise new types of employment. Figures for part-time employed people in Croatia are at a low level, similar to those for Slovenia and Romania, but higher than in Bulgaria, the Czech Republic, Latvia and Lithuania. This indicates that part-time working contracts are, institutionally speaking, developing only slowly. The same applies to employees with a second job. In this indicator, Croatia is ahead of Bulgaria, Poland and Slovenia, although one has to bear in mind that data on secondary jobs could have multiple social and economic consequences which are not always positive.

The regional distribution by NUTS 2 region in Croatia displays higher working activity in the northern part of Croatia compared to the middle and southern (Adriatic) parts. In general, however, NUTS 2 data can be a misleading indicator because there are major differences among the 21 counties within the NUTS 2 regions in Croatia.

The employment/working-age population ratio dropped by $5 \%$ to $56 \%$ in 2010 from a pre-crisis level of $59 \%$ in 2007 , which was already very low. 
Figure 1 - Employment rates, 2010 (age 15-64), country comparison

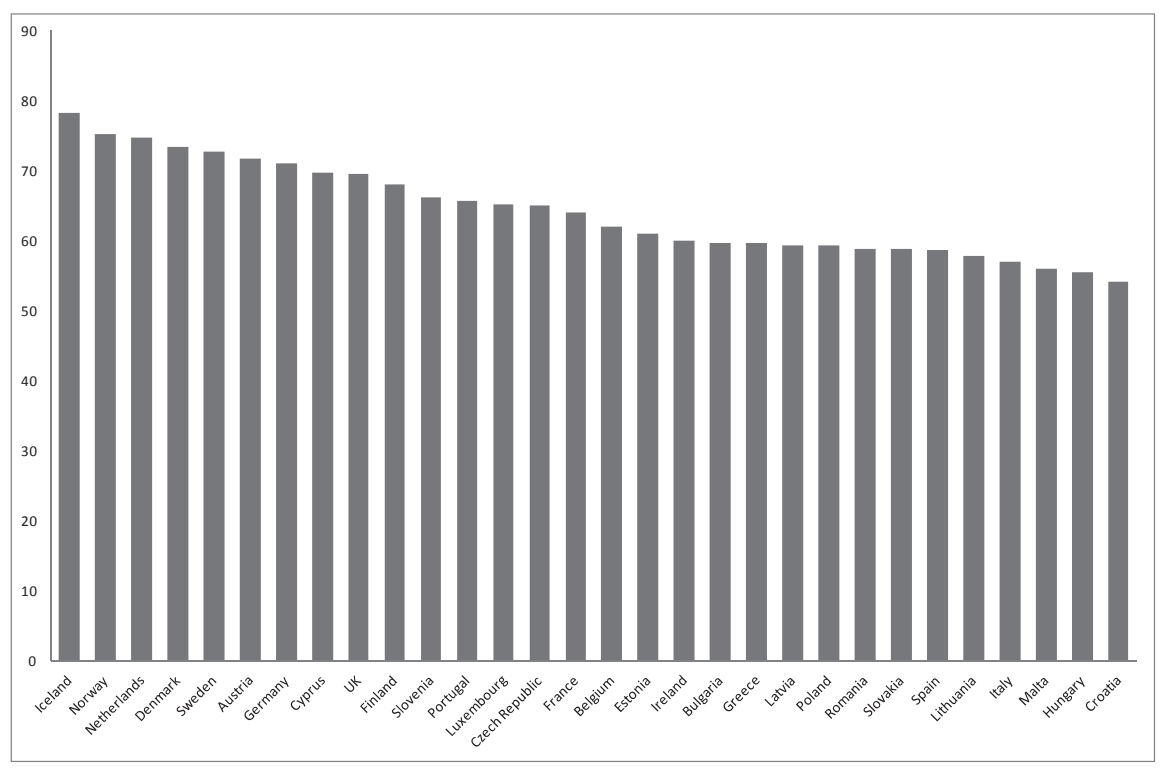

Source: Eurostat

Table 2 shows the composition of employment in Croatia by economic activity, as well as occupation in comparison with EU countries in 2010. Agricultural employment has a much larger share in Croatia (almost ten percentage points above that of the EU-27), while the proportion employed in the service industries is smaller by between three and eight percentage points compared with the EU-27. On the other hand, Croatia has the largest share of employed skilled manual workers (nine percentage points higher than the EU-27), while the proportion of skilled non-manual workers is smaller by eight percentage points than in the EU-27. Interestingly, the proportion of those within elementary occupations is almost at its lowest in Croatia (these figures are lower only in the Czech Republic and Sweden). 
Table 2 - Composition of employed population, 2010 (\%)

\begin{tabular}{|l|c|c|c|c|c|c|c|c|}
\hline & \multicolumn{4}{|c|}{ Economic activity } & \multicolumn{4}{c|}{ Occupation } \\
\cline { 2 - 9 } & $\begin{array}{c}\text { Agricul- } \\
\text { ture }\end{array}$ & Industry & $\begin{array}{c}\text { Market } \\
\text { services }\end{array}$ & $\begin{array}{c}\text { Non- } \\
\text { market } \\
\text { services }\end{array}$ & $\begin{array}{c}\text { Skilled } \\
\text { non- } \\
\text { manual }\end{array}$ & $\begin{array}{c}\text { Low } \\
\text { skilled } \\
\text { manual }\end{array}$ & $\begin{array}{c}\text { Skilled } \\
\text { manual }\end{array}$ & $\begin{array}{c}\text { Elem- } \\
\text { entary } \\
\text { occup- } \\
\text { ation }\end{array}$ \\
\hline EU-27 & 5.2 & 25.4 & 39.2 & 30.3 & 39.9 & 24.9 & 25.5 & 9.8 \\
\hline EA-16 & 3.6 & 25.4 & 40.0 & 31.1 & 40.7 & 25.2 & 24.1 & 10.0 \\
\hline HR & 14.9 & 27.3 & 35.8 & 22.0 & 32.1 & 25.9 & 34.8 & 7.3 \\
\hline
\end{tabular}

Source: Eurostat.

In the manufacturing sector, employment started to decline in 2007 and figures for the change in employment (i.e. the percentage change over the same quarter of the previous year) became negative at the beginning of 2009. ${ }^{3}$ Quarterly changes in employment in the manufacturing sector have remained negative since then. The beginning of a declining trend in employment in the manufacturing sector is explained by the slowdown of economic activity, the primary cause of which was not the external financial and economic crisis that then escalated in the autumn of 2008. In fact, the reasons for the slowdown in economic activity, which was already in evidence in 2007, are to be found in the country's internal economic problems.

The trend in the retail sector is almost the same. In the first quarter of 2011, the retail sector showed a slight recovery, although not enough to leap to a positive scale of employment change for the period.

\section{Unemployment rates ${ }^{4}$}

The unemployment rate, based on Labour Force Survey data, increased from $8.4 \%$ in 2008 to $9.1 \%$ in 2009 and to $11.8 \%$ in 2010 (Eurostat). On the other hand, the unemployment rate based on administrative (CES) data showed a declining trend up to 2008, after which it started to grow (Figure 2). These two measures follow almost the same trend, with the proviso that the administrative rate is always some four to six percentage points higher than the LFS unemployment rate.

The unemployment rate observed in 2008 was at its lowest for some time when the global financial crises erupted in that autumn. Figure 2 shows how unemployment started to rise at the end of 2008. Unemployment rates have increased continuously since then and, in 2010, the unemployment rate reached and then surpassed the levels of 2006. Clearly, the crisis reversed the substantial reduction in unemployment that had

3 CES (2011) Analytical Bulletin No. 1, p. 22.

4 When discussing unemployment statistics, it is important to know the source. Official (registered) unemployment data are taken from Croatian Employment Service (CES) statistics, while other unemployment data are derived from the LFS (Labour Force Survey) produced by the Croatian Bureau of Statistics (CBS). 
occurred in 2008. In the middle of 2011, there were some signs of economic recovery, which might indicate that the unemployment rate could change from its path of increase. However, LFS data on quarterly average unemployment indicate that this is still increasing.

\section{Figure 2 - Unemployment rates}

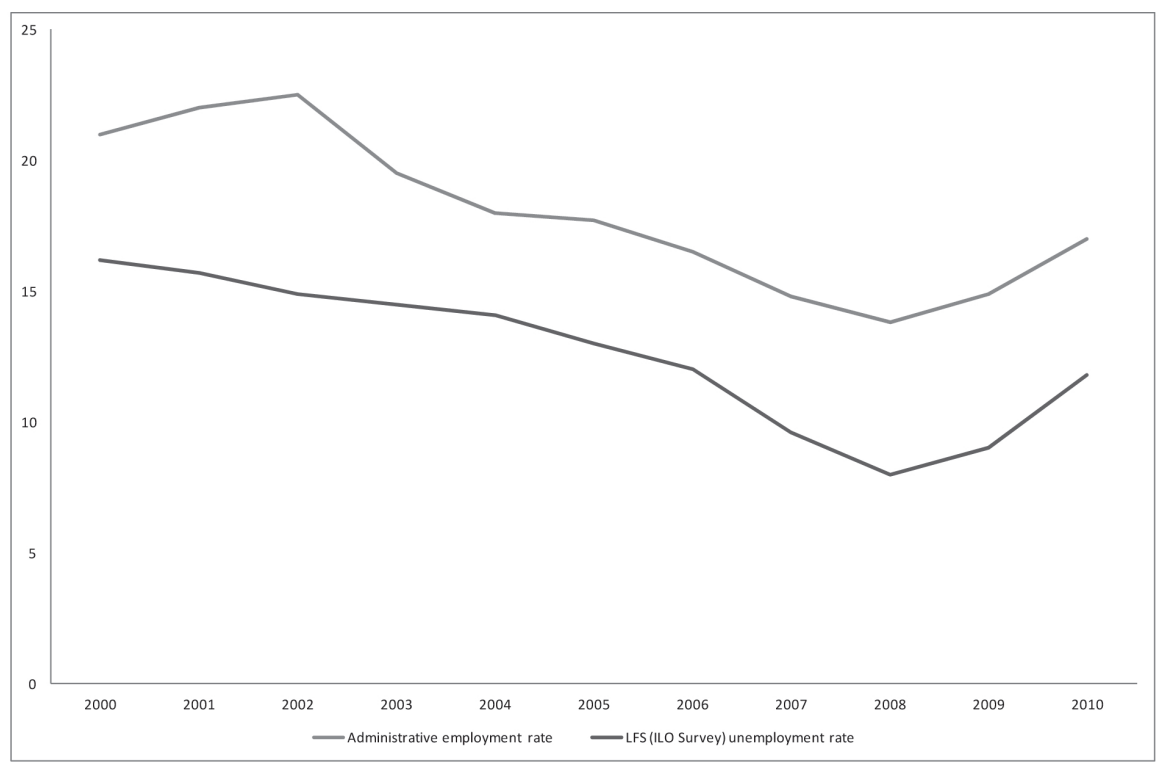

Source: $C B S$

In comparison with other countries in 2010, the Croatian unemployment rate was lower than in Spain, Latvia, Lithuania, Estonia, Slovakia, Ireland, Greece and Portugal, but still somewhat high. Generally, the unemployment rate increased in Croatia by 2.2 percentage points in the period from 2007 to 2010 (from $9.6 \%$ in 2007 to $11.8 \%$ in 2010), but this was still less than in the EU-27 or EU-15 (which showed an increase of 2.5 percentage points in the same period). Unemployment in terms of the number of unemployed people was higher for men in all age groups.

There are large differences in unemployment rates by NUTS 2 region as well as among the counties. According to Eurostat, the lowest unemployment rate is in the North-West region (including the City of Zagreb), at $7.9 \%$, followed by the Adriatic region at $11.3 \%$. However, unemployment rates have increased in all regions after 2008. Significant differences in unemployment rates are evident among the counties. In eight counties, unemployment rates were lower than the national average and in thirteen they were higher. The lowest registered unemployment rate was recorded in the City of Zagreb (7.7 \%) and in Istria (8.5\%). By contrast, the highest unemployment 
rates were recorded in Brod-Posavina (30.4\%), Sisak-Moslavina (30.3\%), VukovarSirmium (30.1\%) and Virovitica-Podravina (29.9\%).

Regional differences in unemployment have many causes, which could explain the imbalance between labour force demand and supply (Botric, 2009). Labour mobility in Croatia is generally low, so it does not contribute to a better matching between labour supply and demand.

In terms of numbers, the average number of unemployed people grew from 263000 in 2009 to 302000 in 2010, and then to 316000 in the first half of 2011 (Figure 3). The percentage of men in total unemployment grew from $40.7 \%$ in 2009 to $45.2 \%$ in 2010 , while the number of women decreased from $59.3 \%$ to $54.8 \%$ in the same period, demonstrating the same gender trends as in EU countries. In unemployment, the crisis hit men more than women.

In terms of age, at the end of 2010 unemployment was higher in all age groups in comparison with the same period in 2009. The highest increase in unemployment was recorded in the $60+(14.9 \%), 30-34(14.4 \%)$ and $20-24(14.0 \%)$ age groups. Compared with the end of 2009, the number of unemployed people increased in all groups of educational qualifications, with the exception of those without any schooling or with incomplete primary education, where a decrease in unemployment of $3.2 \%$ was recorded. The largest increases in unemployment were recorded among those with university and postgraduate degrees $(29.8 \%)$, as well as among those who had completed an initial occupational qualification from a faculty or technical college $(17.6 \%)$.

The long-term unemployed form the most vulnerable cohort in unemployment (i.e. those who have been registered at the CES for more than twelve months). Statistics for long-term unemployment decreased consistently until the autumn of 2009 (SeptemberOctober). After that period, we may observe an increasing number of registered longterm unemployed people. However, the overall number of registered unemployed grew even more rapidly, so the share of long-term unemployed in the total number of unemployed actually decreased (Figure 3). 
Figure 3 - Total number of unemployed people and share of long-term unemployment

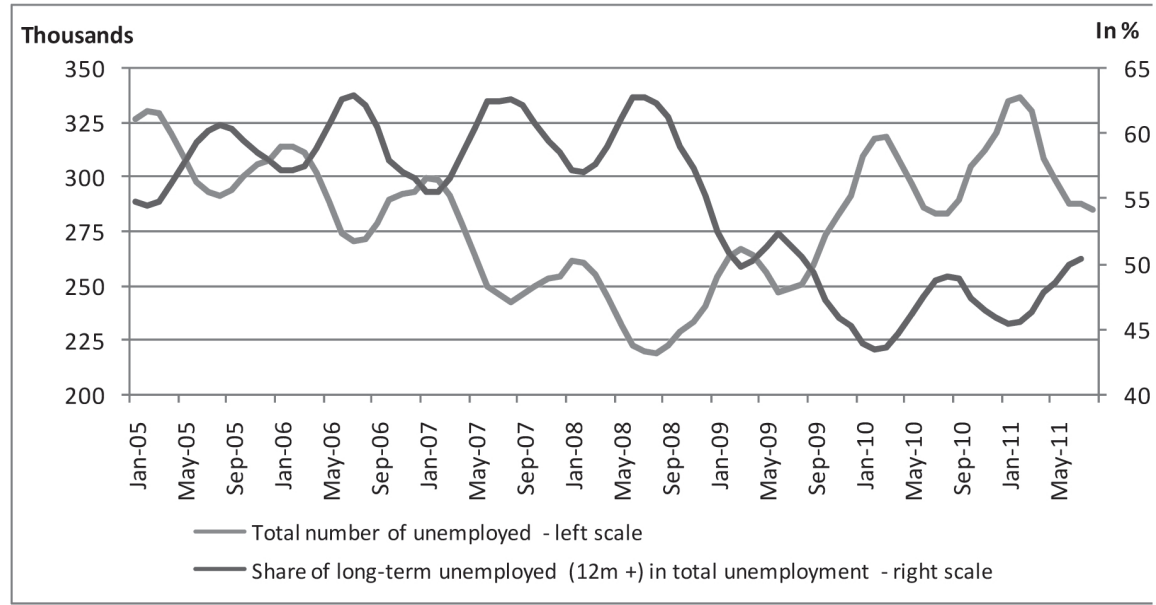

Source: CES

The total of some 150000 people who have been unemployed for more than 12 months represents a significant cohort whose employability presents serious problems. The number of those who had been unemployed for more than three years dropped at the end of 2010 in comparison with the end of 2009, although this was probably not because they had found jobs but rather because they had become discouraged and left the labour market. For instance, in Croatia many older people who were still in the working-age population quit the labour market to take early retirement due to the period of unfavourable economic activity.

\section{Youth unemployment}

Many academic researchers (O'Higgins et al, 2001; Caroleo and Pastore, 2002; Kolev and Saget, 2005; Pastore, 2008), as well as the EU administration, have addressed the importance of youth unemployment. The EU is providing guidelines for decreasing youth unemployment and creating an easier transition from education to work. Across all EU member states and accession countries, young people are confronted by labour market problems similar to those faced by adults, but they are more sensitive to changes in economic conditions. Even though the level of youth unemployment reflects the fluctuations in the overall level of unemployment, youth rates tend to decrease more during 'booms' and increase more in recessions than do the overall rates. ILO (2001) research has shown that an increase in adult unemployment of one per cent is followed by an increase in youth unemployment of approximately two per cent.

One of the reasons for the greater sensitivity of the youth unemployment figures could be that the cost of firing young workers is lower than in the case of more expe- 
rienced adults. Moreover, employment legislation, which restricts the freedom of employers to adjust the level of employment according to their needs, does not protect young workers to the same extent as it protects prime-age workers. That is why it is easier for the employer to fire young employees.

The consequences of unemployment and a lack of employment opportunities for young people are social exclusion, poverty and a future of low-productive activity in the grey economy. The difficulties that young people face when they enter the labour market can affect their behaviour in many ways.

One response to the unfavourable conditions on the labour market is that young people may delay their entrance into it by remaining longer in the education system in order to enhance their chances of finding a job.

Another response to high youth unemployment can be emigration, which is looked upon as a positive opportunity for young people (especially for those who are highly educated) to resolve their problems of unemployment and poverty by finding jobs abroad. However, there are negative effects of emigration: the potential risk of 'brain drain', i.e. the risk of losing the best of the young labour force, as well as the risk of losing investment in education in the home country.

A third consequence of high youth unemployment is the greater employment of young people in the grey economy. Working in the grey economy can certainly help young people reduce the income problems which go with unemployment, but this cannot be a long-term solution.

Croatia has slightly more than half a million young people (i.e. aged 15-24), some $13 \%$ of the whole population. This number is decreasing due to negative natural changes. Among the cohort of young people in the labour force, which numbers around 200000 people, $38 \%$ are active and the rest are inactive. Activity rates are low and have been falling steadily during the last eight years, while inactivity rates are steadily increasing (JIM, 2011). Unemployed young people amount to 70000 in total (Eurostat, 07/2011) while the rate of unemployment is high, about $42.8 \%$ in 2011 (Eurostat); a slight increase in comparison with the end of 2010. This rate of unemployment is exactly double the average rate in the EU-15 (20.2\%) and the EU-27 $(20.7 \%)$. On the scale of youth unemployment rates, Croatia's position is similar to that of Greece and better only than Spain. The youth unemployment rate in Croatia is among the highest, placing Croatia alongside countries like Slovakia, Latvia, Lithuania and Estonia, all of whose rates exceeded $30 \%$ in 2010.

In EU countries, youth unemployment is one of the most challenging problems. The rates of unemployment among young people tend to be higher than those among the adult population. This position is significant for most European countries, where youth unemployment rates tend to be two to three times higher than adult rates. The highest ratio of youth unemployment (the number of unemployed in the 15-24 age group compared to the total population of the same age group) occurs in Spain $(17.8 \%)$, while the average youth unemployment ratio in the EU-27 in 2010 was $9.0 \%$. The Croatian position in this respect $(11.9 \%)$ is better than Latvia (13.9\%) and Estonia (12.6\%). Germany (5.1\%) and Austria (5.2\%) lead with the best records for the youth unemployment ratio. 
Youth unemployment is somehow a more complex problem than adult unemployment. If there is a large imbalance between supply and demand for young workers, it clearly indicates a variety of problems arising for structural reasons. Usually, there are several factors that particularly influence the level of youth unemployment, such as the size of the youth labour force; skills and knowledge being unadjusted to labour demand; lack of work experience; an inflexible education system; insecure and short-term forms of employment contracts; an absence of proper national active labour measures; etc. It would appear that there are many different factors involved, on the sides of both labour demand and labour supply.

On the demand side, employers tend to prefer temporary contracts for young people. Consequently, the main reason for stopping work for teenage young people (aged 15-19) is entrance into education or the end of a temporary job contract. The majority of young adults (20-24 years) are dependent on temporary jobs and do not usually go back into education.

From LFS data in Croatia, it seems that, when young people are searching for jobs, they favour the use of informal networks among family members and friends. However, there are some positive signs that more professional ways of approaching employers are also being used. It is possible to observe a huge gap between employers and education institutions in developing common market-friendly channels for the mutual interest of the employability of young people (for example, currently no school or university in Croatia has a recruitment office).

With regard to education being one of the main factors on the supply side determining the employability of young people, traditional statistics on education are indicative, but still not sufficient. In the majority of countries presented in Figure 4, a lower level of education is seen as contributing to the unemployment rate of young people (other than in Turkey and Romania). Young people with primary education in Croatia had the highest rate of unemployment (46.2\%) in 2010 but, in fact, the rates for all groups, including those with tertiary education (28.4\%), are simply too high. According to a World Bank analysis (World Bank, 2009: 19), youth unemployment in Croatia accounted for about one-third of the newly-registered unemployed in 2009.

The age group between 15 to 24 years is, however, not a homogeneous group in terms of supply characteristics such as education, skills, knowledge and work motivation. 
Figure 4 - Youth unemployment rate (aged 15-24) by education level in 2010, country comparison

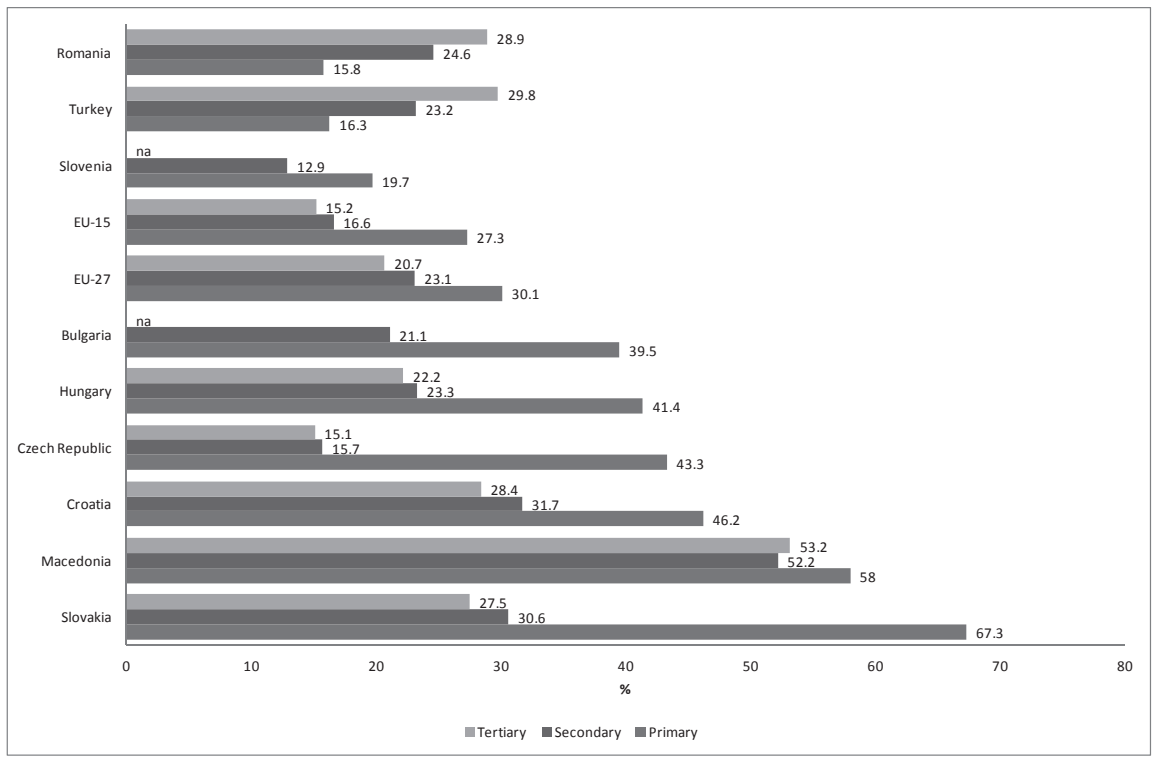

Source: Eurostat

From occupational analysis (JIM, 2011), we may observe that the somewhat static occupational structure of unemployed people reflects a lack of flexibility and adjustment in the education system and amongst job-seekers themselves. Young people in higher education in Croatia are not in a hurry to enter the job market. On the supply side, the rate of employment is directly dependent on the length and quality of the higher education system.

\section{Employment policies and labour market institutions}

\section{Institutional infrastructure for employment policies}

Legislation on the labour market is of primary importance for establishing all other policies and institutions. A new Labour Act in Croatia was adopted in 2009 and came into force on 1 January 2010. The law was aimed at making further adjustments in keeping with EU laws but, because of its complexity and the difficulties in applying it, it is expected that it will lead to an increase in total labour costs. This will further undermine the international competitiveness of the Croatian economy. Some of its provisions have been amended to boost employability and social security conditions among workers, but it is believed that this new Labour Act will, paradoxically, contribute to endangering the overall level of social security in Croatia (Vukorepa, 2010). 
The Employment Protection Legislation (EPL) index was measured for the first and only time so far in Croatia in 2003 (Matković and Biondić, 2003) and was based on OECD methodology. This was carried out after a new Labour Act came into force in 2003, which had the aim of making labour legislation more flexible. The EPL index for Croatia was 2.6, above the EU (2.3) and OECD average (OECD, Investment Reform Index, 2010). Thus, Croatia may be characterised as having some of the most rigid employment protection regulations among EU countries, but some of the least rigid in the region of south-east Europe.

Employment protection legislation is important because it affects job flow by reducing the hiring and firing of workers (job creation and job destruction), and because its effects are usually stronger during economic downturns. The main purpose of employment protection legislation is to provide insurance for workers against labour market risk. It encompasses three main assessments of how regular workers in employment are protected against individual dismissal; what the specific requirements are for collective dismissals; and how temporary forms of employment are regulated. In Croatia, the index for regular employment is 2.6 ; for temporary employment it is 1.9 ; and for collective dismissals, 4.3.

Croatia has much higher severance pay for those with long service records in comparison with other south-east European countries other than Albania, Moldova and Montenegro (OECD, Investment Reform Index, 2010: p. 93). Croatia also maintains restrictive regulation, especially in the case of collective dismissals. Prior notification of a third party (trade unions) is required in the case of collective dismissal; approval is not necessary, but at least three months have to pass following notification before implementation can take place.

In April 2008, the government issued a Resolution adopting the Joint Assessment of Employment Policy (JAP) priorities for the Republic of Croatia. This document presents a set of employment policy objectives necessary for advancing the transformation of the country's labour market and preparing the country for accession to the European Union. The JAP is essential for adjusting and developing the employment system in Croatia so that it will be able to implement the European Employment Strategy both during the accession period and then on becoming a new member state. The JAP provides an assessment of the employment results encompassing the economic and labour market situation as well as employment policies, and it sets out the employment challenges in and action priorities for Croatia.

The priorities which were set were based on the following labour market results: a low employment rate; high long-term unemployment; unemployment among young people; mismatching of skills; low employability of vulnerable groups; and regional disparities. Expected progress in 2009 was seriously undermined by the economic crisis so that the majority of the challenges defined in the JAP were prolonged into the next year. Several joint JAP and JIM (Joint Memorandum on Social Inclusion) conferences were held in 2010 and 2011 to follow up on the progress achieved in implementing the recommendations of these two programmes. Furthermore, the National Employment Promotion Plan adopted for 2011-2012 was based on JAP and JIM goals. 


\section{Fiscal and taxation policies}

The crisis led to a reduction in government budget revenues, while expenditure started to increase. For instance, due to the huge loss of jobs, more funds were needed for social assistance (Table 3), as well as for active labour market programmes. In order to cope with this new situation, the government started to borrow, but it also introduced new measures on the revenue side. The most relevant changes in the Croatian taxation system in 2009 were:

- an increase in the standard rate of VAT from $22 \%$ to $23 \%$

- the temporary introduction of a so-called 'crisis tax' levied on the net income of households (for monthly net incomes between HRK 3000 and 6000 , a $2 \%$ rate was applied while on net income above HRK 6000 , the rate was $4 \%$ )

- the abolition of all tax reliefs in the personal income tax system

- an increase in excise duties on tobacco and fuel.

The 'crisis tax' at the $2 \%$ rate was abolished in June 2010, while the $4 \%$ rate was revoked in November 2010. In addition, in June 2010 the government made further changes to the law on personal income tax by decreasing the number of tax brackets from four to three and reducing the lowest tax rate (from $15 \%$ to $12 \%$ ). These changes were designed to create a lower tax burden for employees, but their ultimate effects remain to be seen. In order to stop excess borrowing, and further increases in the state's debts and deficit, the government brought in the Fiscal Responsibility Act, due to come into force in 2012.

Table 3 - Social benefits drawn from government budget (2006-2010)

\begin{tabular}{|c|c|c|c|c|c|c|c|}
\hline \multirow{2}{*}{ Year } & $\begin{array}{c}\text { Social } \\
\text { benefits }\end{array}$ & \multicolumn{2}{|c|}{$\begin{array}{c}\text { Social security } \\
\text { benefits }\end{array}$} & \multicolumn{2}{c|}{$\begin{array}{c}\text { Social assistance } \\
\text { benefits }\end{array}$} & \multicolumn{2}{c|}{$\begin{array}{c}\text { Social benefits for } \\
\text { employees }\end{array}$} \\
\cline { 2 - 8 } & $\boldsymbol{\epsilon}$ & $\boldsymbol{\epsilon}$ & $\boldsymbol{\%}$ & $\boldsymbol{\epsilon}$ & $\%$ & $\boldsymbol{\epsilon}$ & $\%$ \\
\hline 2006 & 6034926 & 4271110 & 70.77 & 1747079 & 28.95 & 16737 & $0.28 \%$ \\
\hline 2007 & 6567119 & 4657624 & 70.92 & 1883280 & 28.68 & 26216 & $0.40 \%$ \\
\hline 2008 & 7281271 & 5205662 & 71.49 & 2041382 & 28.04 & 34227 & $0.47 \%$ \\
\hline 2009 & 7650154 & 5532430 & 72.32 & 2078932 & 27.18 & 38791 & $0.51 \%$ \\
\hline 2010 & 7810153 & 5902683 & 75.58 & 1884237 & 24.13 & 23232 & $0.30 \%$ \\
\hline
\end{tabular}

Source: MFIN. 
It has been shown that high taxes on salaries contribute not only to higher unemployment, but also to lower participation and employment in the labour market (Cazes and Nesporova, 2007). Grdović Gnip and Tomić (2010), using data from 2008 for 28 countries (the EU plus Croatia), showed that, among EU countries, Croatia belongs within a group with a higher tax burden, a higher employment protection legislation index and a higher unemployment rate (lower employment rate). In addition, they concluded that, when the overall tax burden (including consumer taxes) is considered, its greatest impact is on Croatian workers in the lower economic bracket. Furthermore, Urban (2009) compared the tax wedge in OECD countries and Croatia in 2008 and concluded that the tax wedge in Croatia has a similar value to that in neighbouring countries, but one that is higher than the average value for OECD countries. The same holds true when the 'crisis tax' is added to the calculation for Croatia.

Table 4 - Payroll taxes and contributions for the average manufacturing worker in Croatia (2006-2010)

\begin{tabular}{|l|l|r|r|r|r|r|}
\hline \multicolumn{2}{|c|}{ Monthly $(\boldsymbol{\epsilon})$} & \multicolumn{1}{c|}{$\mathbf{2 0 0 6}$} & \multicolumn{1}{c|}{$\mathbf{2 0 0 7}$} & \multicolumn{1}{c|}{$\mathbf{2 0 0 8}$} & \multicolumn{1}{c|}{$\mathbf{2 0 0 9}$} & \multicolumn{1}{c|}{$\mathbf{2 0 1 0}$} \\
\hline Gross wage & GW & 816.22 & 879.15 & 926.03 & 1002.61 & 988.92 \\
\hline SSC employer & SSC1 & 140.39 & 151.21 & 159.28 & 172.45 & 170.09 \\
\hline SSC employee & SSC2 & 163.24 & 175.83 & 185.21 & 200.52 & 197.78 \\
\hline Personal income tax & PIT & 73.31 & 86.16 & 96.78 & 105.17 & 97.18 \\
\hline Net wage & NW & 579.67 & 617.16 & 644.05 & 696.92 & 693.95 \\
\hline Total labour costs & TLC & 956.61 & 1030.36 & 1085.31 & 1175.06 & 1159.01 \\
\hline Tax wedge & TW & $39.40 \%$ & $40.10 \%$ & $40.66 \%$ & $40.69 \%$ & $40.13 \%$ \\
\hline $\begin{array}{l}\text { Personal average tax } \\
\text { rate }\end{array}$ & PATR & $28.98 \%$ & $29.80 \%$ & $30.45 \%$ & $30.49 \%$ & $29.83 \%$ \\
\hline
\end{tabular}

Note: An 'average worker' corresponds to an adult full-time worker operating in sectors $C$ to $K$, whose earnings are equal to the average wages of the workers in those sectors.

$T W=(S S C 1+S S C 2+P I T) / T L C ; P A T R=(S S C 2+P I T) / G W$.

Source: CBS and authors' calculation.

Table 4 shows how taxes and social security contributions affect wages in Croatia. For an 'average worker', this is quite high: $40 \%$ of total labour costs is accounted for by taxes and social security contributions, while $30 \%$ of the gross wage is paid directly by employees (in the form of income tax and employee contributions). If we compare these results with some other (EU) countries, Croatia is somewhere in the middle; below most developed EU countries, but above most of the new member states (Tomić and Grdović Gnip, 2011). The 'below-average’ worker (earning $67 \%$ of the average wage) is burdened less $(38 \%$ in terms of the tax wedge and a personal average tax rate of 
$27 \%$ ); while the 'above-average' worker (earning $167 \%$ of the average wage) is burdened more (a tax wedge of $45 \%$ and a personal average tax rate of $35 \%$ ).

\section{Education policy}

The overall education results for the Croatian population show an improvement with respect to levels of education because younger generations are achieving better results in tertiary education. The number of pupils and students in education is decreasing from year to year: this is an effect of demography which was anticipated. In tandem with this demographic change, the ratio of pupils per teacher in Croatia has been constantly improving over the years.

The educational structure for the young Croatian population has slowly improved in the last decade, but is still unfavourable. The percentage of all 18 year-olds who were still in any kind of education (all ISCED levels) was $68.6 \%$ in 2010, which still indicates that many young people have remained in education and have not abandoned efforts to improve their knowledge and skills, even if this figure is less than in many EU countries (Eurostat).

In the 20-24 age group, $95.3 \%$ had completed at least upper secondary education, which was much better in comparison with the average in the EU-27 (79.0\%) and the EU-15 (76.6\%). Data on the number of graduates (ISCED 5-6) aged 20-29 in mathematics, science and technology, expressed per 1000 head of the population in their age group, shows a figure of 12.8 (male 16.5), which even bettered Norway's 9.0 (male 12.4), or the USA's 10.3 (male 13.9).

The same trend of improvement can be observed relating to lesser attainment levels (ISCED 2 or less): the share held by the 25-34 age group (as a percentage of the population) was $10.6 \%$ in 2010 compared to $13.3 \%$ in 2006 . Within the group ranging from 25 to 64 , those with the lowest education levels decreased from $25.9 \%$ in 2006 to $23.6 \%$ in 2010 . The over- $65 \mathrm{~s}$ had a substantial share, at $67.6 \%$ in 2006 , but this decreased to $59.8 \%$ in 2010 . However, the indicator of lifelong learning - expressed as the percentage of the adult population aged 25 to 64 participating in education and training - shows poor results: just $2.0 \%$ in 2010, indicating a strong level of backwardness a poor contrast with the average of $9.1 \%$ in the EU-27 and $10.4 \%$ in the EU-15. Lifelong learning is not embedded or developed strongly enough as an integral part of Croatia's working and business culture.

Public expenditure on education in 2008 represented approximately $4.3 \%$ of GDP in Croatia, which is close to the average of $5 \%$ of GDP in the EU-27 (Eurostat, 2008). Out of that, $1.86 \%$ of GDP is spent on primary, $0.93 \%$ on secondary and $0.95 \%$ on tertiary education. Private expenditure on education was $0.36 \%$ of GDP, which was half the EU-27 average of $0.75 \%$ of GDP. There are significant differences in expenditure on private education among European countries, but all of them are using the same schema that includes major public funding of education institutions and minor private funding. In Croatia, the distribution of expenditure on education institutions between public and private sources is $92 \%$ and $8 \%$ respectively.

There is substantial expenditure on public education in Croatia, but the amount allocated in terms of financial aid for pupils and students is too low, at $0.68 \%$ overall and $3.11 \%$ for students in tertiary education, expressed as a percentage of total public 
expenditure on education. There are considerable variations among EU countries in the share of public education expenditure held by the provision of financial support for students. Financial aid, either through transfers and social benefits to students or their families (grants and scholarships), or through loans given directly to students, is an important part of education expenditure because it helps to provide equality of access to education. Matković et al. (2010), in their research on efficiency and accessibility in Croatia's higher education system, found that students' chances of completing their studies are primarily related to socio-economic status and that completion is especially low for students from lower socio-economic groups who do not pay tuition fees. This suggests that the existing instruments of financial support for non-academic costs are inadequate to provide equal access for all to tertiary education in Croatia.

The overall education and training system should be assessed from the perspective of achieving goals such as quality and effectiveness, inclusivity and international accessibility. In the last decade, Croatia has made improvements in these areas, but there is plenty of room for further development in relation to each of these three goals.

Firstly, the quality of education policy may be measured through the results of PISA tests (OECD, 2010) for 15-year-old pupils in mathematics, reading and science. Croatia's result of 474 points was better than those of all other south-east European countries, but was lowest in relation to central and eastern European countries. Croatian pupils achieved better results in science (486) than they did in reading (476) and mathematics (460). Comparing PISA outcome results with input data on public expenditure on education institutions per pupil/student (thousands of euro, pps, Eurostat), Croatia shows relatively poor results compared to Estonia, Poland, Slovakia, Latvia and Lithuania, countries which have lower public expenditure on education institutions but higher PISA ranking results. There is a need to evaluate the many possible factors which influence this weaker effectiveness of public education expenditure.

Secondly, the Legatum Prosperity Index (2010) ranked education in Croatia in 44th place of 110 countries. Croatia had just $90 \%$ of its primary-age children in school and was rated $72^{\text {nd }}$ within the Index. However, this indicator improved at secondary and tertiary levels, where enrolment rates of $94 \%$ and $47 \%$ ranked Croatia in 41 st and 44th place, respectively. More effective public financial aid in tertiary education will certainly improve these results. Inclusivity, or the accessibility of education for everyone in Croatia, is weakest in respect of primary education. On the evidence of the Eurostat figures, lifelong learning is still under-developed and this must change in order to improve the quality of human resources.

Thirdly, international accessibility is also developing only slowly, and student mobility needs to be encouraged more strongly. The Erasmus programme for the funding of study opportunities abroad, which started in 2010, is an example showing the right direction in which this goal may be improved.

\section{Active labour market policies (ALMP)}

Active employment policies are primarily intended as an aid to those among the unemployed who have most difficulties with employment. Part of the mechanisms of collective solidarity, they aim to support vulnerable groups with job assistance, public works, employment subsidies, retraining and skill upgrading, self-employment, wage 
subsidies, etc. Therefore, there are different active policies that achieve in various ways the goals of increasing employability. Such measures can, however, have only a moderate effect on increasing overall activity and in reducing long-term and structural unemployment.

Active labour market policies (ALMPs) play a negligible role in facilitating the better matching of labour demand and supply in response to economic shocks in most south-east European countries in comparison with the EU-15. ALMP expenditure is lower in Croatia than in other European countries (less than $0.05 \%$ of GDP) and much lower in comparison with passive income support programmes, which accounted for $0.32 \%$ of GDP in 2006 (Gligorov et al, 2008: 60). Expenditure data on active and passive measures in Croatia are not yet included in Eurostat statistics or in OECD employment statistics, which is a big hindrance to proper comparative analysis. However, total spending on all labour market programmes, active and passive, is very low - roughly $0.4 \%$ of GDP - which is substantially less than in EU countries of similar income levels (World Bank and UNDP, 2010: 42).

The Croatian Employment Service (CES) is the institution responsible for developing and implementing ALMP measures. Most of the funds for ALMP are allocated from the central government budget, with additional funds from local administration bodies. The efficiency of these measures can be demonstrated by assessing their effects and monitoring costs, which should be an integral part of the process of implementing active employment measures in Croatia. There has been a chronic failure to monitor and analyse the effectiveness of final active employment measures, but the CES began in 2011 to prepare just such an assessment of its implementation of ALMP measures.

ALMP measures that were applied at the time of the pre-crisis boom were focused on resolving the structural problems of unemployment. With the development of the crisis they could not cover, or mitigate, the lack of demand for labour, which led to a rapid growth of inflows into unemployment. Inflows into unemployment are very uneven between the different areas and counties of Croatia. Moreover, the crisis strongly affected even the most educated segments of the labour force, which does not happen at a time of growth.

In mid-summer 2009, due to the deepening crisis and the fears of increasing unemployment, the government adopted emergency measures to support the preservation of jobs. By the beginning of 2010, however, there had been only two applications from enterprises involving the preservation of 27 jobs in total. Essentially, this measure was designed in a positive way but, in practice, it was a complete fiasco. The conditions for support were not properly set and enterprises showed no interest. This failure also indicates that measures for preserving jobs have a shorter-range impact than those targeted at job creation.

ALMP measures continued in 2010 with increased funding in the attempt to encompass a larger number of unemployed people. 
Table 5 - Structure of spending on ALMP measures (\%)

\begin{tabular}{|l|r|r|r|r|r|}
\hline ALMP & $\mathbf{2 0 0 6}$ & $\mathbf{2 0 0 7}$ & $\mathbf{2 0 0 8}$ & $\mathbf{2 0 0 9}$ & $\mathbf{2 0 1 0}$ \\
\hline Public works & 3.3 & 2.5 & 5.6 & 37.4 & 47.0 \\
\hline Non-specific occupational training & 7.3 & 14.1 & 15.7 & 38.9 & 16.7 \\
\hline $\begin{array}{l}\text { Occupational training without commencing } \\
\text { employment }\end{array}$ & - & - & - & - & 0.1 \\
\hline Sub-total of public works and training & 12.7 & 19.9 & 25.3 & 76.3 & 63.8 \\
\hline Hiring subsidy for disadvantaged workers & 9.1 & 10.4 & 9.4 & 1.8 & 1.8 \\
\hline Hiring subsidy for older workers & 21.1 & 20.4 & 19.5 & 3.4 & 4.4 \\
\hline Hiring subsidy for long-term unemployed & 29.3 & 27.4 & 24.8 & 8.8 & 13.8 \\
\hline Hiring subsidy for youth without experience & 27.8 & 21.9 & 21.0 & 6.0 & 10.4 \\
\hline $\begin{array}{l}\text { Self-employment subsidy for long-term } \\
\text { unemployed }\end{array}$ & - & - & - & - & 4.3 \\
\hline Training for known employer & 2.1 & 3.3 & 4.0 & 3.7 & 1.5 \\
\hline $\begin{array}{l}\text { Subtotal of subsidies for employment and } \\
\text { education }\end{array}$ & 87.3 & 80.2 & 74.7 & 23.7 & 36.2 \\
\hline
\end{tabular}

Source: World Bank and UNDP, 2010: 4; CES; authors' calculation.

Table 5 demonstrates that there has been a change in the structure of ALMP measures due to the expansion of the crisis. In 2009, expenditure on active employment measures mostly covered non-specific occupational training and public works. The measures covered employment for a total of 6296 people. In 2010, when the crisis deepened, total funding for ALMP was increased by approximately $110 \%$, while the structure of measures was slightly modified in favour of increased subsidies for employment and education. The funding for ALMP more than doubled, so the number of people covered was twice as high $(13088)$, while the coverage ratio (the percentage of unemployed people participating in active measures such as training, subsidised employment or public works) increased from $2.5 \%$ in 2009 to $4.1 \%$ in 2010 .

The mix of active labour programmes in Croatia was adjusted to the conditions in the labour market in 2009 after the eruption of the global financial and economic crisis. During the economic downturn, demand deficiency meant that ALMP measures were focused on supporting labour demand, fostering job creation and targeting more regular workers and public works, as well as on wage subsidies and self-employment. In 2010, as the crisis continued, ALMP measures were concentrated more on the short-term support of labour demand.

During favourable times of economic recovery and expansion in the future, retraining schemes (in particular for older cohorts), as well as support for educational choices and opportunities (especially for the young), would be important components of a strategy to deal with the long-running problems of structural mismatch. 
Demographic trends and migration expectations

\section{Demographic trends}

Croatia is facing demographic changes of population aging and decline, resulting from the same low fertility rates and increased life expectancy trends that are described in many European countries. Demographic projections by the Croatian Central Bureau of Statistics show that the same trends can be expected over a long period of time (until 2060). According to the latest census in Croatia, the population stood at 4290612 in $2011 .^{5}$ Compared with figures from ten years ago, there has been a drop of around 150000 , which is equivalent to the size of one of our larger cities.

The decrease in the total population, together with the projections for the same trends to continue into the future, affects not only population size but also its structure. Figure 5 demonstrates that the number of young people (aged 0-14) is slowly, but steadily, decreasing over time, while the older cohort of the population (aged 65+) is dramatically increasing. From the economic point of view, the essential part of such demographic changes is their impact on the size and composition of the population of working age (aged 15-64). ${ }^{6}$

By 2050, the population of working age in Croatia could have fallen by 782000 people, or $31 \%$, compared to the situation in 2005 (see Table 7). The severest decline will be in the number of younger people (15-24), which will see a drop of $36 \%$. The same overall decline is foreseen for the population of prime working age (aged 25-54) which will also drop by $31 \%$ by 2050 compared to 2005 . The number of older workers (55-64) will rise in the years to come, but will then decline in a reflection of the shrinking of the overall population. By 2030, there will be $10 \%$ more people aged 55-64 than there were in 2005, and their share of the population of working age will increase to almost $22 \%$, up from $17 \%$ in 2005. From 2030 to 2050, the number of older workers is projected to decrease by $7 \%$. However, the proportion of older workers in the population of working age will increase further, to over $23 \%$ by 2050 .

5 CBS, 2011.

6 For more on the Croatian demographic reality and the labour market challenges that it presents, see Svaljek and Nestic (2008). 
Figure 5 - Share of young people, the population of working age and the elderly in the total population

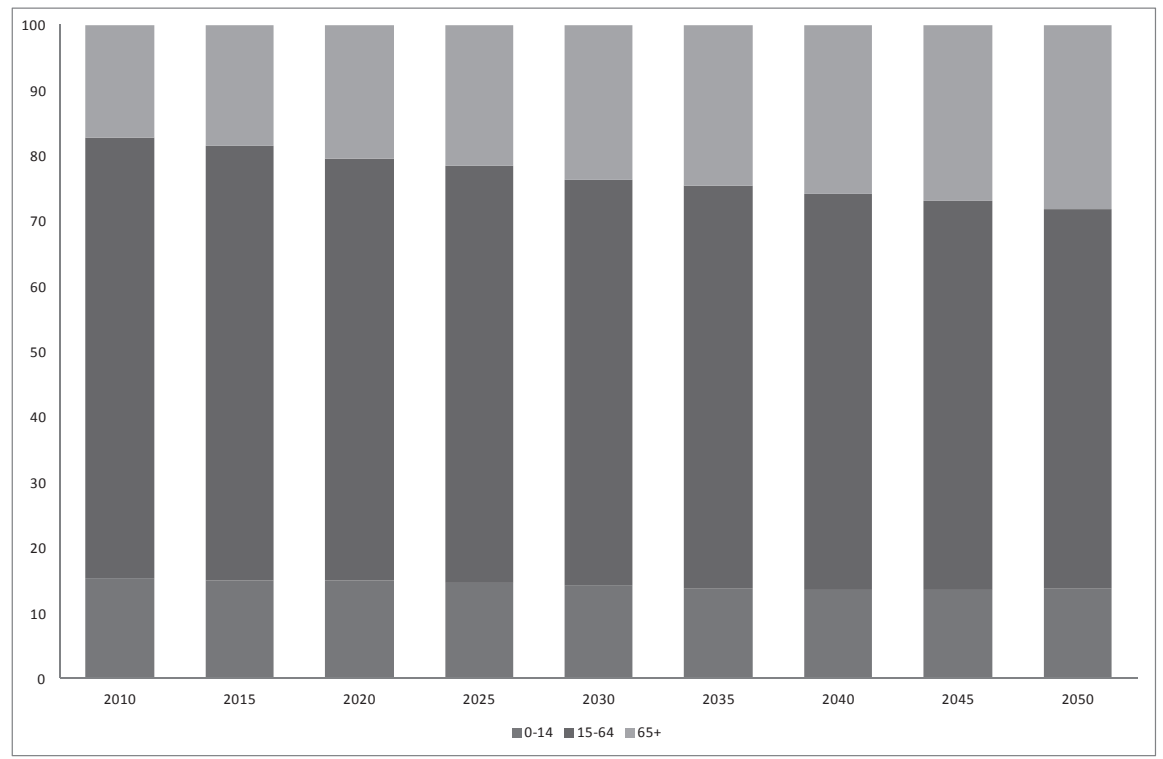

Source: $C B S$ 
Table 7 - Working-age population trends in Croatia, 2005-2050

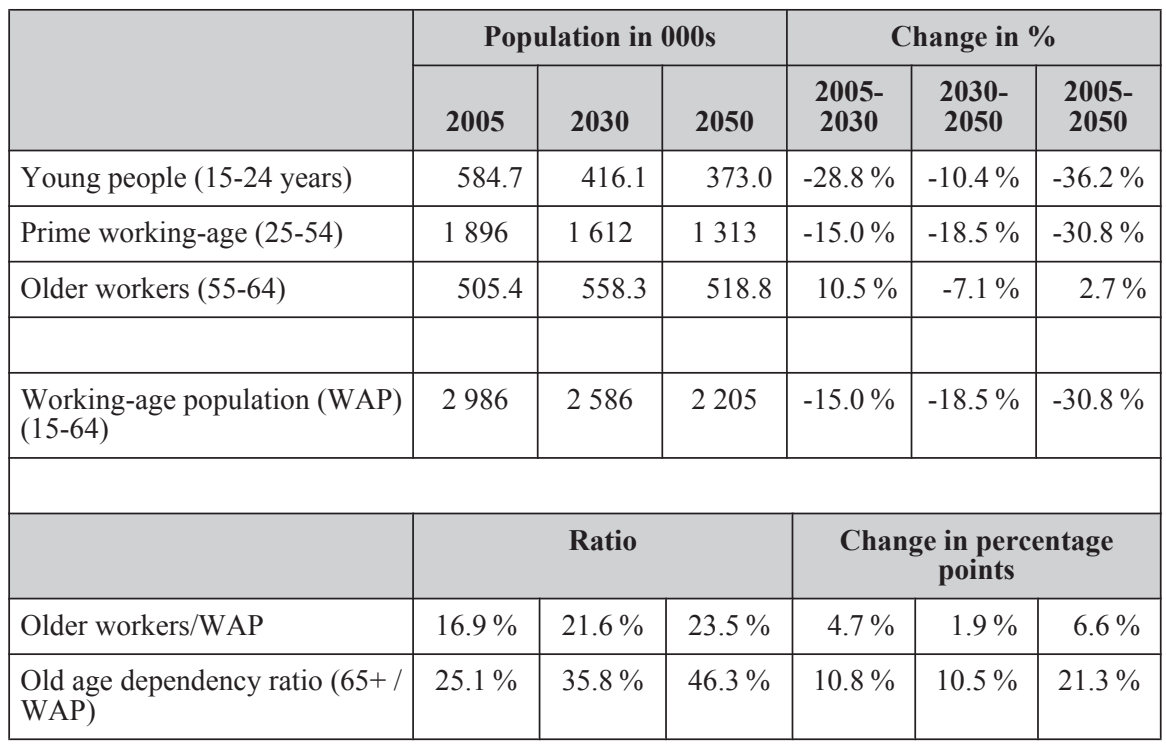

Note: Demographic projection in the baseline variant (medium fertility and medium migration).

Source: $C B S$.

Unfavourable demographic trends are reflected in an increasing old age dependency ratio, which is also not specific to Croatia: the number of elderly people (aged 65 years and over) per person of working age (15-64) will almost double by 2050 (Figure 6). 
Figure 6 - Old age dependency ratio (age 65+ compared to 15-64), country comparison

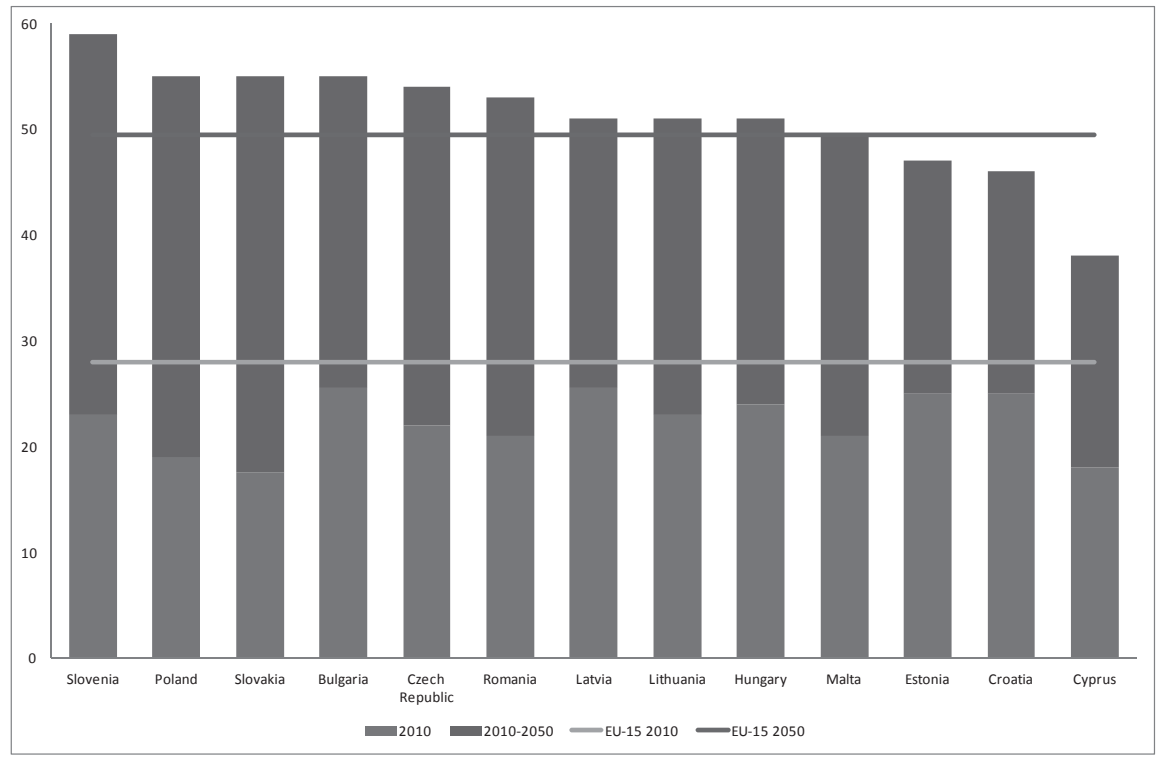

Source: Eurostat and CBS

Long-term demographic changes in the population will bring about structural changes in labour supply, which will have deep effects on the labour market in Croatia (Vehovec, 2009). The structural changes in the population will also need to be taken into account in many aspects of the future economic and social policies that are applied in Croatia.

With reference to the specific demographic problems of labour force aging and shrinking, there is still not enough progress in the employment rates of older workers. Demographic changes are creating a clear economic need for an increased workforce, which could be satisfied domestically by retaining older workers within the labour market. ${ }^{7}$ The Croatian government recently passed a new law raising the limits for retirement, having used a mass early retirement policy for almost two decades. Unfortunately, Croatia had used the concept of early retirement schemes in its restructuring processes to avoid unwanted political repercussions. However, the social costs of the early retirement policy have increased, and they are seriously jeopardising the sustainability of the public pensions system.

7 Švaljek, Sandra (2011) 'Demographic Aging and its Economic Consequences in Croatia' in Andreas Hoff (Ed.) Population Aging in Central and Eastern Europe pp. 135-151. 
Regardless of the current or cyclical features of employment and unemployment on the labour market, on the supply side there is one long-term structural effect caused by demographic changes: the Croatian population is aging. This trend started even before the transition in the 1990s and has continued over recent decades. This has serious implications for the population of working age.

\section{Migration expectations}

The net migration balance in Croatia was positive over a long period of time, but it has recently changed. The number of immigrants in 2009 decreased by over $40 \%$ in comparison with 2008 and previous years while, in the same period, the number of emigrants increased by $33 \%$ (see Table 8 ).

Table 8 - Migration of population in Croatia, 2005-2009

\begin{tabular}{|l|c|c|c|c|}
\hline Year & Immigrants & Emigrants & $\begin{array}{c}\text { Net migration } \\
\text { balance }\end{array}$ & $\begin{array}{c}\text { Rate of net } \\
\text { migration }\end{array}$ \\
\hline 2005 & 14230 & 6012 & 8218 & 1.9 \\
\hline 2006 & 14978 & 7692 & 7286 & 1.6 \\
\hline 2007 & 14622 & 9002 & 5620 & 1.3 \\
\hline 2008 & 14541 & 7488 & 7053 & 1.6 \\
\hline 2009 & 8468 & 9940 & -1472 & -0.3 \\
\hline
\end{tabular}

Source: Central Bureau of Statistics (2011) Migration of population of RH, Statistical information (http:// www.dzs.hr)

The negative net migration balance was probably related not only to the global economic and financial crisis but also to the specific domestic economic and political crisis in Croatia. A significant reduction in the demand for foreign labour in the building, construction and service sectors started at the beginning of 2009. Similar migration results can be expected in 2010 and will continue for as long as Croatia fails to attract a new wave of foreign investment or to improve the efficiency of its public administration. In terms of numbers, net migration does not significantly influence the size of the population. In the future, given the perspective of demographic aging, Croatia will need a much more positive net migration in its population of working age. In the absence of this, the domestic workforce will have to increase its productivity significantly in order to prevent the rate of economic growth from lowering. Vidovic (2009) is also of the opinion that levels of migration are rather low and there is an expectation for future migration flows to be limited, even if overall economic conditions improve considerably.

\section{Conclusion}

The current labour market situation at the end of 2011 in Croatia does not look promising. There are many reasons for this. One is the effect of the global financial and 
economic crisis that hit many economies in the world, including Croatia's, in 2008. Croatia has recorded a negative percentage change in real GDP since 2009, and this has had predictable negative effects on labour demand, resulting in increased unemployment rates, from $9.1 \%$ in 2009 to $11.8 \%$ in 2010 . The pattern of unemployment in Croatia includes big differences among NUTS 2 regions, as well as among the counties (NUTS3). Furthermore, there are differences between genders, age groups and levels of education: men have been hit more than women; the youngest and oldest more than prime-age workers; and the better educated more than the less educated.

Shrinking labour demand is the natural result of reduced economic activity in times of crisis. The problem is knowing how long it will take for the economy to recover, and whether it is more dependent on external economic development trends or on internal employment possibilities and conditions. Croatia already has the lowest employment rate among all old and new European countries, which clearly indicates that there are internal structural reasons for this unfavourable situation. The core problem facing Croatian employment is the low employment rate of the prime-age cohort, with a significant number of workers of prime age either unemployed or working in the grey economy. Low rates of youth employment indicate that young people are remaining in education for longer and, very often, their qualifications do not match labour demand once they eventually enter the labour market.

However, responsibility for the lack of the necessary dynamics of labour flow lies more on the side of labour demand. When a country is dogged by an absence of domestic and foreign investment, with more rigid employment protection laws than in other countries, and with a higher tax burden for employers, it is very difficult to create new jobs and expand overall labour demand.

In a situation of complete economic downturn, employment policies promoting active labour measures provide the right incentive to support labour demand. Unfortunately, active labour market policies currently play a negligible role (less than $0.05 \%$ of GDP) in facilitating the matching of labour supply and demand in Croatia. An examination of all aspects of employment policies reveals that there are more weaknesses than strengths among the internal factors, such as rigid employment protection legislation; the large fiscal deficit; the insufficient practice of lifelong learning; scant financial aid for students; lower efficiency of public expenditure on education; and low expenditure on active labour market policies.

Among the external factors there are some positive expectations connected with accession to the European Union, such as increased mobility opportunities for education and training, and the anticipation of access to more funds from the EU. The unfavourable economic conditions that still prevail in the EU will reduce expectations for the next wave of accession and, if this happens, accession will not influence economic activity in the new member states as it did in the last two waves.

Croatia must rely more on its internal strengths and institutional conditions in order to improve employment possibilities. The political elections at the end of $2011 \mathrm{might}$ bring some positive steps towards economic recovery, which is much needed. Regardless of the temporary economic slowdown, Croatia needs to take into account population aging and the shrinking of the workforce which, in the long run, will change the characteristics of the overall labour force. It is unlikely that migration will contribute 
significantly to the capacity of the workforce, which again makes internal capacity building and adjustment of prime importance.

\section{References}

Bagic, D (2010) Sustav industrijskih odnosa u Republici Hrvatskoj: Hrvatski sindikati između društvene integracije i tržišnog sukoba (Industrial relations system in the Republic of Croatia: Croatian trade unions between social integration and market conflict), doctoral dissertation, Zagreb: Sveučilište u Zagrebu, Filozofski fakultet.

Caroleo, F. E and F. Pastore (2002): Training Policy for Youth Unemployment in a Sample of European Countries Universita degli Studi di Salerno, Centro di Economia del lavoro e di politica economica, Discussion Paper 68, http://www.unisa.it/ uploads/2551/68_dp.pdf [last accessed 10 September 2011].

Cazes, S and A. Nesporova (2007) Flexicurity: a relevant approach in Central and Eastern Europe Geneva: International Labour Office.

CBS (2006) Projekcije stanovništva Republike Hrvatske 2004.-2051. Zagreb: CBS.

CBS (2011) Croatian Bureau of Statistics official website - source: Crostat database www.dzs.hr/default_e.htm [last accessed 10 September 2011].

CES (2011) Analytical Bulletin No. 1, Zagreb: CES.

CES (2011) Analytical Bulletin No. 2, Zagreb: CES.

European Commission (2011) Croatia 2011 Progress Report Commission staff Working Paper

http://www.parlament.gv.at/cgi-bin/eukp.pdf?P_EU=XXIV.pdf/EU/

06/11/061122.pdf [last accessed 13 October 2011).

EIZ (2011) Croatian Economic Outlook Quarterly 13(47) Zagreb: Institute of Economics.

Eurostat (2011) Eurostat official website - source statistics http://epp.eurostat.ec.europa.eu/portal/page/portal/eurostat/home/ [last accessed 13 September 2011].

Eurostat (2008) Population and social conditions - Statistics in focus http://epp.eurostat.ec.europa.eu/cache/ITY OFFPUB/KS-SF-08-046/EN/KS-SF-08-046EN.PDF [last accessed 14 October 2010].

Gligorov, V, A. Iara, M. Landesmann, R. Stehrer and H. Vidovic (2008) Western Balkan Countries: Adjustment Capacity to External Shocks, with a Focus on Labour Markets Research Reports 352

http://www.wiiw.ac.at/?action=publ\&id=details\&publ=RR352 [last accessed $18 \mathrm{Au}$ gust 2011].

Grdović Gnip, A. and I. Tomić (2010) 'How Hard Does the Tax Bite Hurt? Croatian vs. European Worker' Financial Theory and Practice 34(2): 109-142.

ILO (2001): Meeting the youth employment challenge: A guide for employers IFP/ SKILLS and ACT/EMP: Geneva 
http://www.ilo.org/employment/Whatwedo/Instructionmaterials/WCMS_119337/ lang--en/index.htm [last accessed 14 October 2011].

Kolev, A and C. Saget (2005) 'Understanding youth labour market disadvantage: Evidence from south-east Europe' International Labour Review 144(2): 161-187.

Legatum Prosperity Index 2010, baza podataka, http://www.prosperity.com/prosperiscope/ [last accessed 2 September 2011].

Matković, T and I. Biondić (2003) 'Reforma zakona o radu i promjena indeksa zakonske zaštite zaposlenja' Financijska teorija i praksa 27(4): 515-528.

Matković, T, I. Tomić and M. Vehovec (2010) 'Efikasnost nasuprot dostupnosti? O povezanosti troškova i ishoda studiranja u Hrvatskoj' Revija za socijalnu politiku 17(2): 215-237.

Meznaric, S and P. L. Stubbs (2010) The social impacts of emigration and rural-urban migration in central and eastern Europe Interim country report: Croatia VC/ 2010/0026.

MFIN (2011) Ministry of Finance official website http://www.mfin.hr/hr/ [last accessed 15 September 2011].

Ministry of Health and Social Welfare (2010) JIM Report on the implementation of the joint inclusion memorandum (JIM) of the Republic of Croatia http://www.ec.europa.eu/social/BlobServlet?docId=4335\&langId=en [last accessed 2 September 2011].

Nestic, D. and I. Rašić Bakarić (2010) Minimum Wage Systems and Changing Industrial Relations in Europe: National Report Croatia http://www.eizg.hr/minimumwage-systems-and-changing-industrial-relations-in-europe-en-US/532.aspx [last accessed 2 September 2011].

OECD (2010) PISA 2009 Results: Executive Summary http://www.oecd.org/dataoecd/ 34/60/46619703.pdf [last accessed 30 September 2011].

OECD (2010) Investment Reform Index 2010, Paris: OECD.

O'Higgins, N, F. Pastore, I. Beleva and A. Ivanov (2001) 'Targeting Youth Employment Policy in Bulgaria' Economic and Business Review 3(2): 113-135.

Pastore, F (2008) 'Employment and Education Policy for Young People in the EU. What Can New Member States Learn From Old Member States? Bulletin of Comparative Labour Relations 65: 235-254.

Rebac, I (2006) 'Kolektivno pregovaranje u Hrvatskoj' ('Collective Bargaining in Croatia') Radno pravo 3(6): 17-34.

Sokcevic, Svjetlana (2009) 'Mogućnosti i izazovi socijalnog dijaloga u Hrvatskoj' in Vojmir Franicevic and Vlado Puljiz (Eds.) Rad u Hrvatskoj: Pred izazovima budućnosti Zagreb: Centar za demokraciju i pravo Miko Tripalo and Pravni fakultet Sveučilišta u Zagrebu, pp. 303-324. 
Švaljek, Sandra and Danijel Nestic (2008) 'The Croatian demographic reality and labour market challenges' in Maja Vehovec (Ed.) New Perspectives on a Longer Working Life in Croatia and Slovenia pp. 53-64, Zagreb: EIZ and FES.

Švaljek, Sandra (2011) 'Demographic Aging and its Economic Consequences in Croatia' in Andreas Hoff (Ed.) Population Aging in Central and Eastern Europe pp. 135-151, London: Ashgate.

Tomić, Iva and Ana Grdović Gnip (2011) Labour markets and taxes in Europe: How much do governments bite the hands that feed them? Saarbrücken: VDM Verlag Dr. Müller.

Urban, Ivica (2009) Some Characteristics of the 'Crisis Tax' in Croatia Press Releases No. 11 http://www.ijf.hr/eng/releases/11.pdf [last accessed 13 January 2010].

Vehovec, Maja (2009) 'Ponuda rada i izazovi starenja radne snage - Hrvatska u EU perspektivi' in Vojmir Franicevic and Vlado Puljiz (Eds.) Rad u Hrvatskoj: Pred izazovima budućnosti Zagreb: Centar za demokraciju i pravo Miko Tripalo and Pravni fakultet Sveučilišta u Zagrebu, pp. 17-47.

Vidovic, Hermine (2009) Labour mobility within the EU in the context of enlargement and the functioning of the transitional arrangements, Country case: Croatia No. 4, WIIW, http://www.wiiw.ac.at/ [last accessed 28 July 2011].

Vukorepa, Ivana (2010) 'Novi zakon o radu' Revija za socijalnu politiku 17(2): 333-337.

World Bank and UNDP (2010) Croatia: Social Impact of the Crisis and Building Resilience Report No. 55111-HR, Washington, DC: World Bank. 